\title{
INTERVENSI ULTRASOUND DAN MUSCLE ENERGY TECHNIQUE LEBIH MENURUNKAN DISABILITAS LEHER DARIPADA INTERVENSI ULTRASOUND DAN MYOFASCIAL RELEASE TECHNIQUE PADA KASUS MYOFASCIAL PAIN SYNDROME OTOT UPPER TRAPEZIUS DI DENPASAR
}

\author{
Ari Wibawa ${ }^{1}$, Ni Luh Nopi Andayani ${ }^{2}$,Anak Ayu Nyoman Trisna Narta Dewi ${ }^{3}$ \\ 1,2,3 Departemen Fisioterapi Fakultas Kedokteran Universitas Udayana \\ Email : ariwibawafk@unud.ac.id
}

\begin{abstract}
ABSTRAK
Latar Belakang: Myofascial Pain Syndrome otot upper trapezius adalah suatu kondisi nyeri baik akut maupun kronik dari otot ataupun fascia menyangkut fungsi sensoris motoris ataupun otonom. Nyeri myofascial dapat bersifat lokal atau regional, seperti pada leher, bahu, biasanya unilateral atau lebih berat di salah satu sisi. Tujuan: Untuk membuktikan Intervensi Ultrasound dan Muscle Energy Technique lebih menurunkan disabilitas leher daripada Intervensi Ultrasound dan Myofascial Release Technique pada kasus Myofascial Pain Syndrome otot Upper Trapezius di Denpasar. Metode: Penelitian ini menggunakan metode Randomized Pre Test dan Post Test Control Group Desain. Penelitian ini menggunakan 36 subjek yang dibagi menjadi 2 kelompok, Kelompok Perlakuan I dengan Ultrasound dan Muscle Energy Technique dan Kelompok Perlakuan II dengan Ultrasound dan Myofascial Release Technique. Ke dua kelompok perlakuan diberikan perlakuan selama 4 minggu. Alat ukur yang digunakan untuk disabilitas leher adalah Neck Disability Index (NDI). Hasil Penelitian: Hasil independent t-test yang memperlihatkan hasil perhitungan beda rerata disabilitas leher yang diperoleh nilai $p=0,372(p>0,05)$. Kesimpulan: Intervensi ultrasound dan muscle energy technique lebih menurunkan disabilitas leher daripada intervensi ultrasound dan myofascial release technique pada kasus myofascial pain syndrome otot upper trapezius
\end{abstract}

Kata Kunci: Myofascial Pain Syndrome otot upper trapezius, Ultrasound, muscle energy technique, myofascial release technique, Neck Disability Index.

\section{INTERVENTION OF ULTRASOUND AND MUSCLE ENERGY TECHNIQUE MORE REDUCE NECK DISABILITY FROM ULTRASOUND INTERVENTION AND MYOFASCIAL RELEASE TECHNIQUE IN MYOFASCIAL PAIN SYNDROME MUSCLE UPPER TRAPEZIUS CASE IN DENPASAR}

\begin{abstract}
Background: Myofascial Pain Upper trapezius muscle syndrome is a condition of both acute and chronic pain from muscle or fascia involving sensory, motoric, or autonomic functions. Myofascial pain can be local or regional, such as the neck, shoulders, usually unilateral or more severe in one side. Objective: To prove Ultrasound and Muscle Energy Technique Interventions to reduce neck disability more than Ultrasound and Myofascial Release Technique Interventions in the case of Myofascial Pain Syndrome Upper Trapezius muscle in Denpasar. Method: This study uses the Randomized Pre-test method and the Design Group Post Test Control. This study used 36 subjects divided into 2 groups, First Treatment Group with Ultrasound and Muscle Energy Technique and II Treatment Group with Ultrasound and Myofascial Release Technique. The two treatment groups were given treatment for 4 weeks. The measuring instrument used for neck
\end{abstract}


disability is the Neck Disability Index (NDI). Results: The results of the independent t-test which showed the results of the calculation of the difference in mean neck disability obtained $\mathrm{p}=0.372$ ( $>$ > 0.05). Conclusion: Ultrasound intervention and muscle energy technique further reduced neck disability than an ultrasound intervention and myofascial release technique in the case of myofascial pain syndrome upper trapezius muscle

Keywords: Myofascial Pain Syndrome, upper trapezius muscle, Ultrasound, muscle energy technique, myofascial release technique, Neck Disability Index.

\section{PENDAHULUAN}

Myofascial Pain Syndrome otot upper trapezius adalah suatu kondisi nyeri baik akut maupun kronik dari otot ataupun fascia menyangkut fungsi sensoris, motoris ataupun otonom. Nyeri myofascial dapat bersifat lokal atau regional, seperti pada leher, bahu, biasanya unilateral atau lebih berat di salah satu sisi. Keadaan ini akibat adanya statik low level muscle exertion yang berlebihan dari otot upper trapezius seperti mengetik 30 menit lebih secara berulang, meja kerja yang terlalu rendah, menggendong tas berat serta gerakan bahu secara terus-menerus tanpa istirahat sehingga terjadi repetitif mikro trauma ${ }^{1}$. Nyeri otot dapat menetap dengan variasi dari ringan hingga sangat berat dan biasanya tidak hilang dengan sendirinya, memerlukan penanganan yang cukup serius sebelum terjadi disabilitas yang parah. Prevalensinya laki-laki dan perempuan tidak ada perbedaan, terutama pada usia antara 3060 tahun $^{2}$.

Berbagai macam penanganan kasus Myofascial Pain Syndrome otot upper trapezius ini di antaranya ultrasound, muscle energy technique, myofascial release technique. Intervensi Muscle Energy Technique(MET) memiliki prinsip memanipulasi halus, kekuatan tahanan gerak yang minimal yaitu sebesar $20 \%$ dari kekuatan otot, adanya kontrol pernapasan dengan pengulangan optimal ${ }^{3}$. Penelitian yang dilakukan oleh Nambi, et al., menunjukkan Pemberian muscle energy technique efektif dalam meningkatkan lingkup gerak sendi ${ }^{3}$.

Pada Intervensi lain Myofascial release technique (MRT) merupakan teknik kombinasi dari tekanan manual pada otot spesifik dan peregangan secara simultan ${ }^{4}$. Pada riset yang dilakukan oleh Barnes dkk didapatkan MRT mampu mengurangi nyeri, peningkatan kinerja atletik, meningkatkan fleksibilitas dan untuk mendapatkan postur yang lebih baik. Intervensi ini termasuk standar dalam praktik Fisioterapi dan hasilnya juga mampu meningkatkan kemampuan fungsional pada leher.

Dari latar belakang di atas, penulis tertarik untuk memberikan intervensi pada 2 kelompok. Kelompok Perlakuan diberikan intervensi Ultrasound dan Muscle energy technique, Pada Kelompok Kontrol diberikan intervensi Ultrasound dan Myofascia release technique

\section{METODE PENELITIAN}

\section{A. Rancangan Penelitian}

Penelitian ini menggunakan studi eksperimental dengan rancangan Randomized Pre Test dan Post Test Control Group Desain, di mana sampel dibagi menjadi dua kelompok yang dilakukan secara acak. Kelompok Perlakuan 1 dengan intervensi Ultrasound dan Muscle Energy Technique sedangkan kelompok Perlakuan 2 dengan intervensi Ultrasound dan Myofascial Release

\section{B. Tempat dan Waktu Penelitian}

Penelitian ini dilakukan di praktik Fisioterapi Ketut Darmayasa dan I Made Niko Winaya di Denpasar. Penelitian dilakukan selama 4 minggu dari bulan Oktober sampai November 2018.

\section{Populasi dan Sampel}

Populasi target pada penelitian ini adalah semua penderita myofascial pain syndrome di Denpasar. Populasi terjangkau pada penelitian ini adalah semua penderita myofascial pain syndrome yang datang ke tempat Praktik Fisioterapi Ketut Darmayasa dan Fisioterapi Tukad Banyusari di Denpasar. Yang sudah memenuhi kriteria inklusi yaitu 
usia >30 tahun, dengan myofascial pain syndrome pada otot upper travezius

Pengambilan sampel menggunakan teknik consecutive sampling, di mana pasien yang telah memenuhi kriteria akan dimasukkan dalam penelitian ini sampai kurun waktu tertentu. Jumlah sampel sebanyak 36 sampel.

\section{Prosedur Penelitian}

Melakukan proses perijinan pada institusi tempat penelitian. Subjek menandatangani informed consent, peneliti mencocokkan sampel yang sesuai dengan kriteria inklusi dan memilih 36 sampel dengan teknik consecutive sampling dan peneliti melakukan random alokasi dengan teknik simple random sampling, kemudian masuk pada tahap pelaksanaan. Tahap pelaksanaan: (a) Pengukuran disabilitas leher dengan menggunakan Neck Disability Index (NDI) (b) Kelompok Perlakuan 1 menerima perlakuan Ultrasound dan Muscle Energy Technique sedangkan Kelompok Perlakuan 2 menerima perlakuan Ultrasound dan Myofascial Release Technique selama 4 minggu.

\section{E. Analisis Data}

Analisis data untuk pengujian statistik pada penelitian ini adalah Uji normalitas dengan Saphiro Wilk test, Uji Homogenitas dengan Levene test dan uji hipotesis perbedaan penurunan disabilitas leher antara kelompok perlakuan dengan kelompok kontrol dengan menggunakan uji independent $t$ - test

\section{HASIL PENELITIAN}

\section{Distribusi Data Sampel Berdasarkan Jenis Kelamin}

Distribusi sampel berdasarkan jenis kelamin tertera pada tabel 1.

Tabel 1. Distribusi Data Sampel Berdasarkan

\begin{tabular}{ccc}
\multicolumn{3}{c}{ Jenis Kelamin } \\
\cline { 2 - 3 } $\begin{array}{c}\text { Jenis } \\
\text { Kelamin }\end{array}$ & $\begin{array}{c}\text { Kel. } \\
\text { perlakuan }\end{array}$ & Kel. kontrol \\
\hline Laki-Laki & $8(44,4 \%)$ & $11(61,1 \%)$ \\
Perempuan & $10(55,6 \%)$ & $7(38,9 \%)$
\end{tabular}

Pada tabel 1. di atas, kelompok 1 perempuan lebih banyak dari laki-laki dan pada kelompok 2 laki-laki lebih banyak dari perempuan.

Distribusi data berdasarkan umur pada kelompok 1 memiliki rerata umur $(36,78 \pm 5,462)$ dan kelompok $2(38,50 \pm 6,271)$

\section{Uji Normalitas dan Homogenitas data}

Hasil uji normalitas dan homogenitas dapat dilihat pada tabel 2 .

Tabel 2. Hasil Uji Normalitas Dan Homogenitas Neck Disability Index Myofascial Pain Syndrome Otot Upper

Trapezius Sebelum Dan Sesudah Intervensi

\begin{tabular}{|c|c|c|c|}
\hline \multirow{4}{*}{$\begin{array}{c}\text { Kelompo } \\
\text { k Data }\end{array}$} & \multicolumn{2}{|c|}{ Shapiro Wilk Test } & \multirow{4}{*}{$\begin{array}{c}\text { Uji } \\
\text { Homogenita } \\
\text { s } \\
\text { (Levene's } \\
\text { Test) }\end{array}$} \\
\hline & Kelompo & Kelompo & \\
\hline & k 1 & k 2 & \\
\hline & $P$ & $P$ & \\
\hline
\end{tabular}

NDI

Sebelum

Intervensi

$0,359 \quad 0,453$

0,223

NDI

Sesudah

0,419

0,396

0,926

Intervensi

Selisih

$0,260 \quad 0,076$

0,142

Tabel 3 di atas, menunjukkan hasil uji normalitas mendapatkan nilai probabilitas untuk kelompok data sebelum intervensi pada Kelompok perlakuan adalah $\mathrm{p}=0,359$ ( $\mathrm{p}>$ $0,05)$ dan sesudah intervensi nilai $\mathrm{p}=0,419$ ( $\mathrm{p}$ $>0,05)$ sedangkan pada Kelompok kontrol sebelum intervensi nilai $\mathrm{p}=0,453(\mathrm{p}>0,05)$ dan sesudah intervensi nilai $\mathrm{p}=0,396$ ( $\mathrm{p}>$ $0,05)$. Hasil tersebut menunjukkan data berdistribusi normal.

Pada uji Homogenitas didapatkan nilai $\mathrm{p}=0,223(\mathrm{p}>0,05)$ untuk kelompok sebelum intervensi dan untuk kelompok sesudah intervensi nilai $\mathrm{p}=0,926(\mathrm{p}>0,05)$ yang memiliki arti bahwa data homogen. Maka dari itu pengujian hipotesis menggunakan uji statistik parametrik.

3. Uji beda perbandingan rerata penurunan nyeri pada otot upper trapezius 


\section{sebelum dan sesudah pada kedua kelompok}

Hasil uji perbandingan penurunan nyeri pada otot upper trapezius tertera pada tabel 3 .

Tabel 3. Hasil Uji Independent T-test

\begin{tabular}{|c|c|c|c|c|}
\hline & Kelompok & $\mathrm{N}$ & Rerata \pm SB & $\mathrm{p}$ \\
\hline sebelum & $\begin{array}{c}\text { Kelompok } \\
1\end{array}$ & 18 & $30,15 \pm 1,909$ & \multirow{2}{*}{0.732} \\
\hline \multirow{5}{*}{ sesudah } & $\begin{array}{c}\text { Kelompok } \\
2\end{array}$ & 18 & $30,68 \pm 1,709$ & \\
\cline { 2 - 4 } & $\begin{array}{c}\text { Kelompok } \\
1\end{array}$ & 18 & $19,54 \pm 3,270$ & \multirow{2}{*}{0,227} \\
\hline \multirow{2}{*}{ Selisih } & $\begin{array}{c}\text { Kelompok } \\
1\end{array}$ & 18 & $18,83 \pm 2,079$ & \\
\cline { 2 - 4 } & $\begin{array}{c}\text { Kelompok } \\
2\end{array}$ & 18 & $11,83 \pm 1,518$ & \multirow{2}{*}{0,372} \\
\hline
\end{tabular}

Pada Tabel 3. menunjukkan hasil perhitungan beda rerata disabilitas leher yang diperoleh adalah nilai $\mathrm{p}=0,372(\mathrm{p}>0,05)$ pada selisih antara sebelum dan sesudah perlakuan. Hal tersebut berarti secara statistik tidak membuktikan bahwa intervensi ultrasound dan muscle energy technique lebih menurunkan disabilitas leher daripada intervensi ultrasound dan myofascial release technique pada kasus myofascial pain syndrome otot upper trapezius.

\section{PEMBAHASAN}

\section{Karakteristik Sampel}

Karakteristik sampel pada penelitian ini yaitu pada Kelompok Perlakuan subjek dengan jenis kelamin laki-laki yaitu 8 orang $(44,4 \%)$ dan jenis kelamin perempuan yaitu 10 orang $(55,6 \%)$, sedangkan pada Kelompok Kontrol subjek dengan jenis kelamin laki-laki adalah 11 orang $(61,1 \%)$ dan perempuan adalah 7 orang $(38,9 \%)$. Berdasarkan data di atas, bahwa $52,8 \%$ laki-laki lebih banyak terkena myofascial pain syndrome dibandingkan dengan wanita yang hanya $47,2 \%$. Hal ini sesuai dengan pernyataan
Atmaja yang menyebutkan antara laki-laki dan perempuan memiliki prevalensi yang sama ${ }^{5}$.

Berdasarkan umur subjek, kelompok perlakuan memiliki rerata umur $36,78 \pm 5,462$ tahun dan kelompok kontrol memiliki rerata umur 38,50 $\pm 6,271$ tahun. Hasil ini didukung oleh pernyataan Wadee yang menyebutkan $67 \%$ orang dengan rentang usia 20 sampai dengan 69 tahun pernah mengalami kejadian ini ${ }^{6}$. Pada umur tersebut bisa dikatakan orang produktif di mana salah satu kegiatan di depan komputer atau kondisi statis yang lain dalam jangka waktu lama dan berulang-ulang.

\section{Intervensi Ultrasound dan Muscle Energy Technique lebih menurunkan disabilitas leher daripada intervensi Ultrasound dan Myofascial Release Technique pada kasus Myofascial Pain Syndrome otot Upper Trapezius}

Berdasarkan dari hasil uji statistik menggunakan uji independent $t$ test untuk melihat perbandingan rerata penurunan NDI pada otot upper trapezius sebelum dan setelah intervensi pada kedua kelompok. Pada Kelompok perlakuan didapatkan nilai rerata selisih antara nilai sebelum dan sesudah intervensi yaitu 10,61 $\pm 2,279$ dan Kelompok kontrol memiliki rerata selisih antara nilai sebelum dan sesudah intervensi yaitu $11,83 \pm 1,518$ sedangkan nilai $\mathrm{p}=0,372$ ( $>>0,05)$. dapat disimpulkan bahwa tidak ada perbedaan yang bermakna arau signifikan antara intervensi ultrasound dan muscle energy technique dengan intervensi ultrasound dan myofascial release technique dalam menurunkan disabilitas leher pada kasus myofascial pain syndrome otot upper trapezius.

Hal ini dikarenakan adanya intervensi ultrasound dapat memberikan efek pada kondisi myofascial pain syndrome (MPS) seperti efek peningkatan sirkulasi, perbaikan metabolisme dan proses regenerasi sel, efek analgesik, dengan mekanisme seperti thermogenesis dan perubahan metabolik. Dalam beberapa tahun terakhir, sensitisasi sentral mekanisme dianggap memainkan peran dalam patofisiologi MPS ${ }^{7}$. Hal ini diperkuat oleh penelitian Gülis Kavadar dkk 
yang berjudul efficacy of conventional ultrasound therapy on myofascial pain syndrome yang menyatakan Ultrasound efektif dalam kasus MPS ${ }^{8}$.

\begin{tabular}{crr}
\multicolumn{2}{c}{ Pemberian } & myofascial release \\
technique setelah ultrasound akan
\end{tabular} memberikan efek yang menyebabkan struktur-struktur di dalam jaringan konektif akan menghasilkan histamin yang mempunyai peranan sebagai vasodilator. Selain itu akan terjadi difusi yang lebih meningkat dan sempurna untuk mengeluarkan produk sisa metabolisme jaringan ke darah yang disebabkan dari peningkatan permeabilitas kapiler dan venule (vena kecil) ${ }^{9}$. Myofascial Release dapat menstimulasi GTO untuk menurunkan aktivitas motorik akibat pembebanan mekanis yang terjadi pada otot yang mengalami ketegangan. Hasil yang diperoleh sangat baik dalam meningkatkan kemampuan fleksibilitas fascia ${ }^{10}$.

Pada sisi lain pengaplikasian muscle energy technique juga baik dalam menurunkan disabilitas leher di mana menerapkan 2 konsep, yaitu post isometric relaxation (PIR) yang melibatkan golgi tendon dan reciprocal inhibition yang melibatkan muscle spindle (RI). Muscle energy technique merupakan teknik relaksasi otot dengan cara pemberian kontraksi isometrik sebelum dilakukan stretching yang bertujuan sebagai proprioceptive neuromuscular facilitation untuk penguatan atau meningkatkan tonus otot untuk yang lemah, menurunkan tonus otot yang terlalu tinggi, meregangkan otot dan fascia, meningkatkan fungsional muskuloskeletal, meningkatkan mobilitas sendi, dan meningkatkan sirkulasi lokal serta menurunkan nyeri ${ }^{11}$. Proses mekanisme PIR melibatkan respons golgi tendon organ yang akan merangsang impuls saraf aferen memasuki akar dorsal di tulang belakang dan bertemu dengan inhibitory motor neuron. Hal ini berhenti di debit neuron aferen motoric impuls yang akan mencegah kontraksi yang terus menerus untuk relaksasi otot agonis. Sedangkan untuk proses mekanisme RI terjadi akibat receptor stretch terhadap serat otot spindle. Berdasarkan teori pompa otot, adanya kontraksi otot akan meningkatkan perfusi di dalam jaringan saat kontraksi otot, pembuluh darah vena otot akan mengalami kompresi dan mendorong darah ke jantung. Pada saat relaksasi, tonus pada serabut otot pada dinding pembuluh darah vena akan menurun sehingga akan melebarkan lumen vena yang akan menurunkan tekanan. Hal ini akan menyebabkan peningkatan tekanan pada pembuluh darah arteriovena sehingga meningkatkan aliran darah ke otot tersebut dan menyebabkan penurunan konsentrasi cytokine dan mengurangi stimulasi nosiseptor perifer $^{11}$.

Penelitian Amer tahun 2017 dengan judul Efficacy of Muscle Energy Technique versus Myofascial Release in Management of Patients with Cervical Myofascial Pain menyatakan bahwa kedua teknik intervensi tersebut efektif dalam MPS dan menurunkan skala disabilitas leher ${ }^{6}$. Beberapa pernyataan penelitian mengenai penurunan nyeri myofascia akan berdampak terhadap peningkatan kemampuan fungsional leher.

\section{SIMPULAN}

Berdasarkan penelitian tersebut dapat kesimpulan bahwa :

1. Intervensi ultrasound dan muscle energy technique sama baiknya dengan intervensi ultrasound dan myofascial release technique dalam menurunkan disabilitas leher pada kasus myofascial pain syndrome otot upper trapezius

\section{SARAN}

Adapun saran yang berdasarkan pada temuan dan kajian dalam penelitian ini adalah

1. Berdasarkan hasil penelitian ini maka ultrasound, muscle energy technique dan, myofascial release technique dapat digunakan untuk intervensi fisioterapi dalam penatalaksanaan nyeri yang diakibatkan oleh myofascial pain syndrome otot upper trapezius

2. Diharapkan penelitian selanjutnya menambah variabel dan alat ukur yang lebih objektif sehingga penatalaksanaan kasus myofascial pain syndrome dapat dilakukan lebih komprehensif. 


\section{DAFTAR PUSTAKA}

1. Hardjono, J., Ervina, A. 2012. Pengaruh Penambahan Contract Relax Stretching pada Intervensi Interferensial Current dan Ultrasound Terhadap Pengurangan Nyeri pada Sindroma Miofasial Otot Supraspinatus. Jakarta: Universitas Esa Unggul.

2. Luo J.J., Dun N.J. 2013. Chronic pain: Myofascial pain and fibromyalgia. $J$ Physical Med \& Rehabilitation. Vol. 1, No. 6.

3. Nambi, G. S., Sharma, R., Inbasekaran, D., Vageshiya, A., Bhatt, U. 2013. Difference in Effect Between Ischemic Compression and Muscle Energy Technique on Upper Trapezius Myofascial Trigger Points : Comparative Study. International Journal of Health and Allied Sciences, Vol. 2, No. 1.

4. Schneider M. 2005. Chiropractic management of myofascial trigger points and myofascial pain syndrome: A systematic review of the literature. $J$ Manipulative Physiol Ther. Vol. 32:14-24.

5. Atmadja, A. S. 2016. Sindrom Nyeri Myofascial. Continuing Medical Education, pp. 176-179. Retrieved from http://www.cdkjournal.com/index.php/CD K/article/view/29

6. Wadee, A. N. 2017. Efficacy of Muscle Energy Technique versus Myofascial Release in Management of Patients with Cervical Myofascial Pain. International Journal of ChemTech Research, Vol. 10, No.2: 468-476.

7. Woolf, C. J. 2011. Central sensitization: implications for the diagnosis and treatment of pain. NIH Public Access, 215. doi: 10.1016/j.pain.2010.09.030

8. Kavadar, G. N. 2015. Efficacy of conventional ultrasound therapy on myofascial. AGRI PAIN. doi:doi: 10.5505/agri.2015.48569

9. Maruli W. O. 2014. Perbandingan Myofascial Release Technique Dengan Contract Relax Stretching Terhadap Penurunan Nyeri Pada Sindrom Myofascial Otot Upper Trapezius. Majalah Ilmiah Fisioterapi Indonesia. Retrieved from http://ojs.unud.ac.id/index.php/mifi/article/ view/8470।

10. Pawaria, S. 2015. Comparing Effectiveness of Myofascial Release and Muscle Stretching on. Indian Journal of Health Sciences and Care, 8-13. doi: 10.5958/2394-2800.2015.00002.4

11. Fryer, G. 2011. Muscle energy technique: An evidence-informed approach. Int $J$ Osteopath Med, 3-9. Retrieved from https://core.ac.uk/download/pdf/10831752. pdf 